Historic, Archive Document

Do not assume content reflects current scientific knowledge, policies, or practices. 

Anse th

$n \rightarrow 52$

A.H.D. No. 52
Bureau of Animal Industry

to a naci.
1.9

An $52 \mathrm{Ah}$

no. 52

THE UNITED STATES MORGAN HORSE FARM

An Outline of Experimental Work in Progress or Recently Conducted with Horses, Sheep, Cattle, and Pastures

\section{Prepared by}

Ralph W. Phillips, Damon A. Spencer, S. R. Speelman, W. H. Black, J. O. Wilizams, and I. P. Earle Bureau of Animal Industry, United States Department of Agriculture

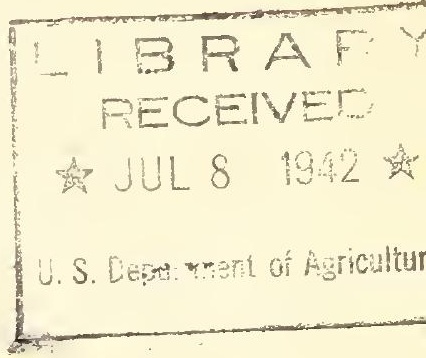

Contents Page

Introduction

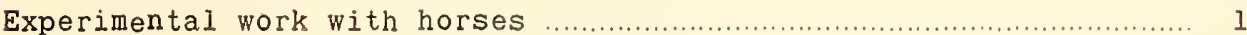

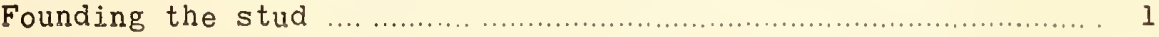

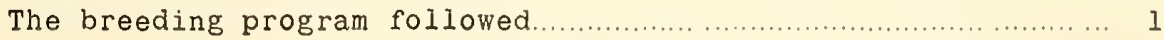

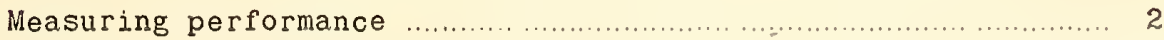

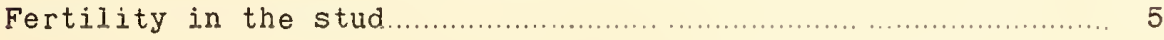

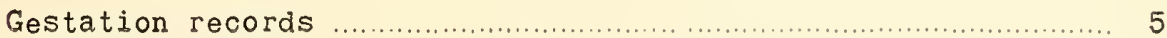

Birth weights and sex of foals ....................................... 6

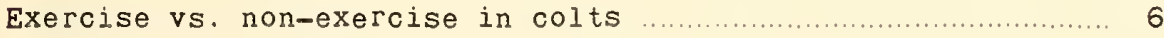

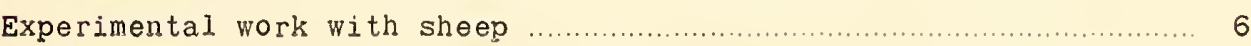

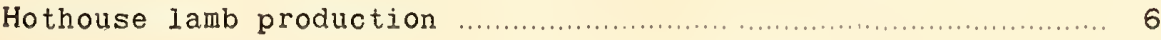

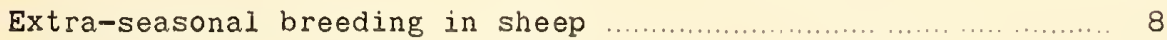

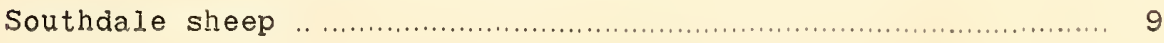

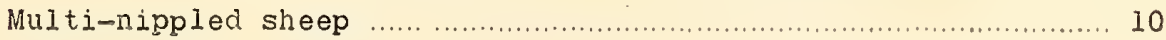

Experimental work with dual-purpose cattle ............................... 10

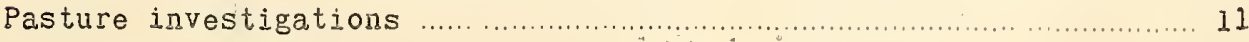

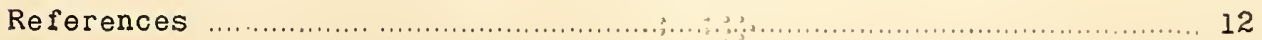


\begin{tabular}{c}
$\vdots$ \\
\hdashline \\
\hdashline
\end{tabular} 
EXPERIMENTAL WORK AT THE UNITED STATES MORGAN HORSE FARM

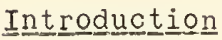

The United States Morgan Horse Farm, located in the town of Weybridge, Vt., two miles north of Middlebury, was established in 1907 for the purpose of perpetuating and improving the Morgan breed. The original farmstead consisted or 400 acres and some buildings and was given to the United States Department of Agriculture by Colonal Joseph Battel. of Midhlebury. Colonel Battell was a life-long, ardent admirer and breeder of Morgans as well as founder and publisher of the Morgan Horse and Register (now called the American Morgan Horse Register), official stud book of the breed. The area of the farm was increased by a subsequent gift from Colonel Battell in 1908 and by purchase of a large tract (about 550 acres) from Middlebury College in 1917. In all, the United States Morgan Horse Farm now comprises approximately 1,000 acres of gently rolling land, underlain with limestone, which is particularly adapted to the raising of pasturage and hay ancis suitable for the production of light-type horses.

Animals maintained at the U. S. Morgan Horse Farm for experimental purposes at the present time include approximately 75 Morgan horses of all ages and 165 mature sheep.

\section{Experimental Work with Horses}

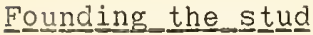

During the early stages of the horse breeding work at the United States Morgan Horse Farm a large amount of time was spent in locating, selecting, and collecting a suitable band of mares and stallions. This proved to be a quite difficult task, because there had been a long-continued diffusion of Morgan blood through crossing with other breeds, particularly the Standardbred and American Saddle Horse, and representative individuals carrying desirable blood lines had become scarce and widely scattered throughout many states. To obtain the foundation stud stock, purchases were made in Illinois, Iowa, Kansas, Kentucky, New Hampshire, Rhode Island, Texas, Washington, and Vermont. Moreover, some privately owned stallions were patronized. In making early selections of breeding stock and when planning their matings, particular stress was laid on the matter of size and quality, for it was desired to improve the old-type Morgan in both these respects. And such efforts have been successful, for present-day members of the stud are not only considerably taller and heavier on the average than their predecessors, but such increases have not been attained by sacrificing quality. Also, continued efforts to improve the general riding qualities of Morgans now appear to be resulting in individuals having better performance at the walk, trot, and canter.

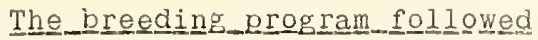

During the development of a herd, flock. ol stud, it frequently happens that the progeny of one sire or some particular cross or mating becomes predominant and other lines of breeding iend to be eliminated. This has occurred in the progress 
of the work at the United States Morgan Horse Farm. Here, General Gates (666 A. M. R: ) wes the original stallion to head the stud, and although many cther sires made some contributions toward its improvement in the early years, most of the animals there now trace to "the General" through his son, Bennington ( 5693 A. M. R.), and his grandson, Mansfield (7255 A. M. R.). General Gates was bred by Colonel Battell, Bennington was produced by the United States Morgan Horse Farm, while Mansfield was obtained as a gift from C. C. Stillman, President and Registrar of the Morgan Horse Club for many years. Because of the prepotency of General Cates and his progeny. the breeding system practiced at this station has been largely one of line-breeding to sires of this line. A chart showing the pedigrees of all animals one year old or over in the stud at the United States Morgan Horse Farm in 1941 is given in figure 1. Examination of this tabulation reveals that some inbreeding has been practiced, but on the whole the amount has been rather small. Of the 49 animals one year old or over present in 1941, 25 showed no intreeding. The coefficient of inbreeding for the remaining 24 ranged from 1.56 to 14.84 percent

\section{Measuring performance}

In a long-time experimental horse breeding program, such as the one in progress at the United States horgan Horse Farm, it is essential to have specific measures of merit and performance that can be recorded regularly and used in judging the trends and results obtained. Developments of such measures and standards for a breed such as the Morgan, which is used both for pleasure and utility purposes, is quite complicated because it involves a multiplicity of factors. For example, to have the greatest utility value, Morgans must be sound, sturdy, active, well-mannered individuals, capable of performing well either under saddle or in harness. Further, the work in harness must be characterized by tractability and level-headedness, but the horses should not be so docile that they lack the vim and spirit demanded in good sadale stock. In working out its standards for judging the merits of stock produced at the United States Morgan Horse Farm, the Department has cevised a system for scoving all individuals periodically from binth to maturity and a series of tests to determine their efficiency and capabilities for driving and riding purposes. At present the tests are applied to all stock when three years old. So far as possjble, all animals are handied alike during the tests and ro horse is tried until it has undergone a preliminary training period of appoximately 4 months. The tests now in use were decided upon after a number of preliminary tests and experiments, and they are as follows:

(1) Speed of walking and trotting and length of stride at these gaits, in carriage, pulling 60 percent of body weight. The horse covers one mile at each gait. Length of stride is measured over the second, fifth, and last laps of the mile test at each gait. The track is one-eighti mile in length. The carriage used is a two-wheeled training cart. Weight pulled includes cart, driver, harness, and necessary ballast in the cart.

(2) Speed of walking and trotting and length of strice at these gaits, under saddle, carrying 20 percent of body weight. The horse covers one mile at each gait. Length of stride is measured the same as in the tests in carriage. Weight caried includes saddle, bridle, rider, and any necessary additional weight, carried as lead weights in pockets under the saddle. 


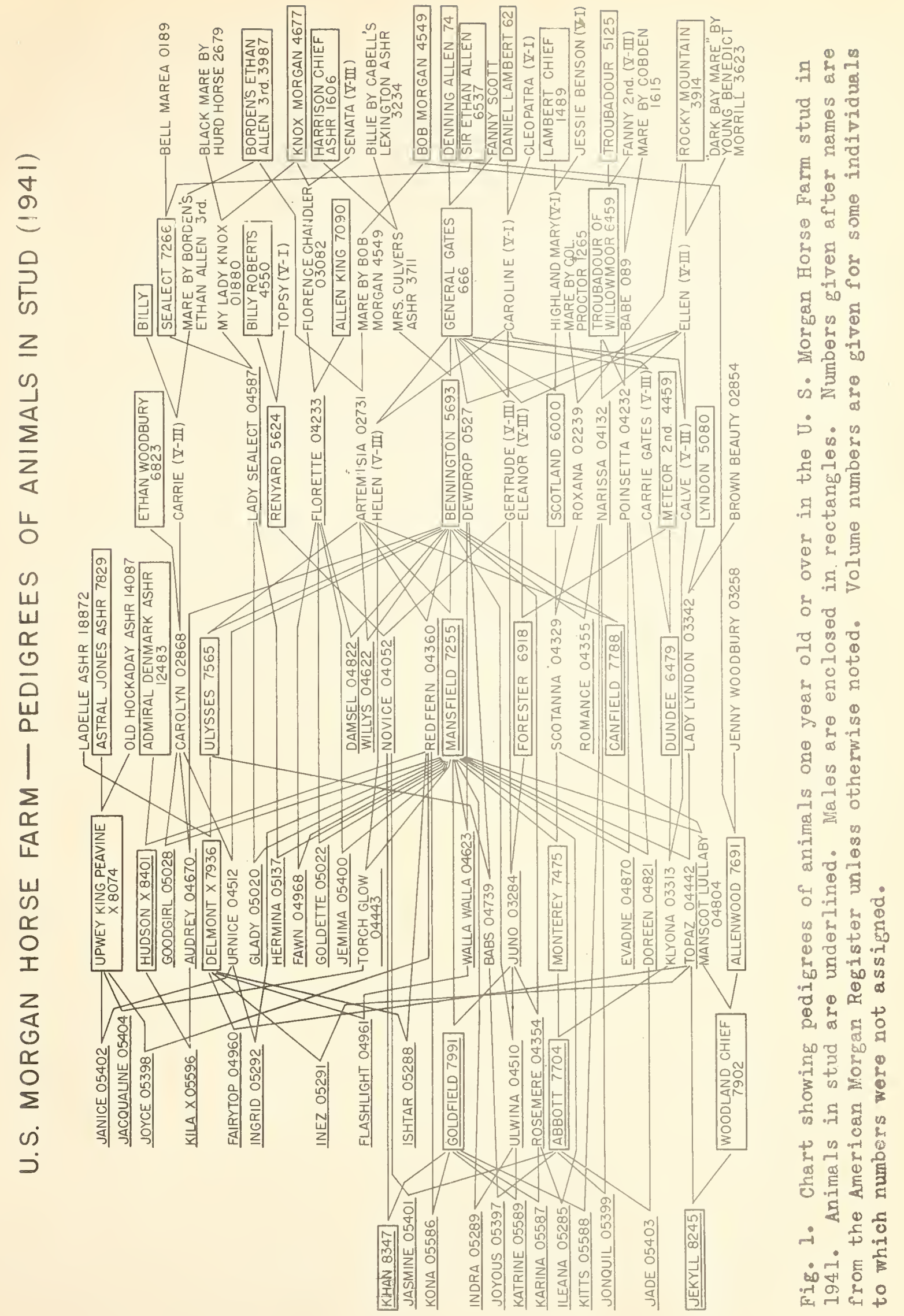


(3) Endurance is measured by a test at the trot in carriage for five miles. The horse "warms up" by walking one-half mile prior to the test. Respiration and heart rates are taken before removing animals from their stalls, at the end of the test, and 5, 10, and 15 minutes after the end of the test. Length of stride is recorded over laps number 1, 10, 20, 30, and 40 (each lap is one-eighth mile). Each animal is scored for signs of fatigue at the end of the test.

(4) Each horse is taken on a cross-country ride of 11.5 miles. It is over unpaved country roads and includes a number of grades, some of them being quite steep. The course is marked so that each horse covers it in the same manner, walking over sections designated to be covered at this gait, and trotting or cantering over others. In all, the horse walks 4.7, trots 5.7, and canters 1.1 miles. Each horse carries 20 percent of its weight. At the end of the ride the time required to cover the course is recorded and the horse is scored for signs of fatigue, ease of handling and response to commands, performance of gaits, and ease of gaits from the standpoint of the rider.

Data collected in these tests will be used in the selection of breeding animals and in detailed studies of the factors that determine the utility value of a horse.

Physiological studies in relation to performance have been undertaken for the purpose of deriving some useful physiological or biochemical measure which can be applied in parallel with physical measures of performance in estimating the ultimate effects of variations in nutrition on the performance ability of horses. In these studies observations are made on the chemical changes produced in the blood by controlled amounts of exercise and on the rate of recovery from the changes produced by exercise. Animals of different ages and conditions of training and animals known to differ in endurance and performance ability are used in these studies. 
Fentility_in $\underline{\text { in }}$ the stud

A study of fertility in the lorgan horse stud from 1928 through 1938 revealed that 67.3 percent of the mares bred produced foals. The data for each year are summarized in the following table:

\begin{tabular}{|c|c|c|c|c|c|c|c|}
\hline \multirow{3}{*}{ Year } & \multirow{3}{*}{$\begin{array}{c}\text { Number } \\
\text { mares } \\
\text { bred }\end{array}$} & \multicolumn{4}{|c|}{ Number_of mares foaling from= } & \multirow{2}{*}{\multicolumn{2}{|c|}{ Ma res foaling }} \\
\hline & & 1 & 2 & 3 & 4 & & \\
\hline & & service & services & services & services & Number & Percent \\
\hline 1928 & 24 & 15 & 1 & & & 16 & 66.7 \\
\hline 1929 & 21 & 13 & $I$ & & & 14 & 66.7 \\
\hline 1930 & 15 & 6 & 2 & 3 & & 11 & 73.3 \\
\hline 1931 & 19 & 13 & 1 & & & 14 & 73.7 \\
\hline 1932 & 19 & 10 & & & & 10 & 52.6 \\
\hline 1933 & 19 & 9 & 3 & & & 12 & 63.2 \\
\hline 1934 & 18 & 5 & 4 & & 1 & 10 & 55.6 \\
\hline 1935 & 21 & 13 & 3 & 1 & & 17 & 80.9 \\
\hline 1936 & 22 & 9 & 4 & 1 & & 14 & 63.6 \\
\hline 193 & 24 & 15 & 2 & & & 17 & 70.8 \\
\hline $193 \underline{8}$ & - 21 & 13 & $Z_{2}$ & 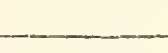 & - & -15 & 71.4 \\
\hline Totals & 223 & 121 & 23 & 5 & 1 & 150 & 67.3 \\
\hline
\end{tabular}

The effect of age of mares at breeding time on fertility has been studied and these data are sumarized below:

\begin{tabular}{|c|c|c|c|}
\hline Age of mares & Mares_b bred & \multicolumn{2}{|c|}{ Mares foaling } \\
\hline Year $\underline{s}$ & Numbere $\underline{\underline{n}}$ & Number & Per coent \\
\hline $3-6$ & 40 & 28 & 70.0 \\
\hline $7-10$ & 69 & 53 & 76.8 \\
\hline $11-14$ & 48 & 38 & 79.2 \\
\hline $15-18$ & 30 & 18 & 60.0 \\
\hline $19-22$ & 23 & 10 & 43.5 \\
\hline $23-26$ & 13 & 3 & 23.1 \\
\hline
\end{tabular}

\section{Gestation records}

Data on the duration of gestation and the effect of age on gestation have also been summarized and these figures are presented below:

\begin{tabular}{|c|c|c|c|}
\hline \multirow{2}{*}{$\begin{array}{c}\text { Age of mares } \\
\text { Years }\end{array}$} & \multirow{2}{*}{$\begin{array}{l}\text { Number } \\
\text { of mares }\end{array}$} & \multicolumn{2}{|c|}{ Leng th of gestation perion } \\
\hline & & Range & Average \\
\hline $3-6$ & 28 & $320-363$ & 344.8 \\
\hline $7-10$ & 48 & $329-362$ & 343.1 \\
\hline $11-14$ & 38 & $324-363$ & 34.4 .7 \\
\hline $15=18$ & 18 & $316-362$ & 340.3 \\
\hline $19-22$ & 10 & $332-361$ & 343.4 \\
\hline $2 \underline{2} 3=26$ & 2 & $3 \underline{3} \underline{6}-\underline{3} \underline{5} \underline{9}$ & 347.5 \\
\hline Total & 144 & $316=363$ & $343.7 \pm 8.9$ \\
\hline
\end{tabular}




\section{Birtin weights and sex of foals}

The average birth weight of all foals was 10.3 .6 pcunds with a standard deviation of 14.4 pounds. There was a tendency for older mares to produce heavier foals than younger mares, the correlation between age of mare and birth weight being 0.25. Horse colts were slight]y but not significantly haavier than mare colts, the respective birth weights being 104.1 and 103.2 pounds. Or 144 foals born alive and sexed, 54.2 percent were males.

\section{Exercise vs. non-exercise in colts}

In nutrition experiments vith horses it is frequently necessary to maintain the animals in small quarters where there is opportunity for only very limited exercise. The effects of such treatrent upon the animals need to be known in order to interpret properly the reslits of experiments conducted under these conditions. For this reason a study is being conducted to determine the effects of restricted exercise during the growing period upon the growth, development, and ujimate performance of horses. Foals are selected at weaning time and paired according to similarity of breeding, type, and size. Up until 3 years of age one member of each pair is allowed the freedom of a large padock with no grazing and the other is confined in a large box stall. Both members of the pair are fed on rations that are estimated to meet all nutritive requirements. Records are kept on the rate of growti as indicated by weight and body measurements. From the age of 3 years both animals in each pair are given identical training and exercise. At the end of a suitable training period their ability to perform is measured and scored. Data are not yet available on a sufficient number of animals to warrant a sumary of results.

\section{Experimental Work with Sheep}

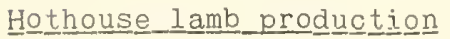

Dorset sheep are noted for the production of "hothouse lambs", the fancy market lambs raised as sucklings during the winter and forced to a high market inish at the early age of about $3 \frac{1}{2}$ months. Experiences of lamb producers have shown that while Dorset lambs can be produced to satisfy the hothouse lamb trade, advantages would probably result from crossmbeeding Dorset ewes with Southdown rams. It has also seemed likely that crossmbeeding sheep with certain other breed combinations might offer advantages in this specialized phase of lamb production

The Bureau of Animal Industry undertook to obtain definite information on this enterprise by conducting sheep breeaing experiments in hothouse lamb production at the Morgan Horse Farm during the 8 years, 1932 to 1940. The breeding sheep used in this project included 105 ewes and 7 rams. During the 8 years 393 matings were made with these breeding sheep and 259 were raised to an average age of 103 days, when they averaged a market slaughter grade of 1.47 (1-) or low Choice. Thj.s low rote of 66 lambs raised per 100 matings is accounted for, in large measure, by the fact that these lambs had to be born during the fall and early winter in order to classify as hothouse lambs, and many ewes fail to conceive at the required time 
during the summer. Even many of the Dorset ewes of this experiment were inclined to fail in such extra-seasonal conceptions.

In an effort to find the breeds or breed combinations of sheep best suited to the required extra-seasonal breeding and the early finishing qualities so necessary for hothouse lambs, the ewes bred by the Bureau in this undertaking included 26 Dorsets, 24 Corriedales, 20 Tasmanian Merinos, 17 Dorset x Tasmanian Merinos, and 18 Dorset x Delaine Merinos. During the first 4 years the Dorset ewes were bred to Dorset rams, and in the last 4 years to Southdown rams. The average annual net return per Dorset ewe for lambs, lamb pelts, and the wool from the ewes was $\$ 0.87$ when they were bred to Dorset rams, as compared with $\$ 3.94$ when they were bred to Southdown rams. This advantage of $\$ 3.07$ per ewe has real significance in favor of such cross-breeding for hothouse lambs.

The accompanying table shows the details of this and additional findings with other breeds and crossbreds used in hothouse lamb production.

\begin{tabular}{|c|c|c|c|c|c|c|c|c|}
\hline \multirow[b]{2}{*}{ Items compared } & \multicolumn{8}{|c|}{ Breeding of lambs } \\
\hline & $\mid$ Dorset $\mid$ & $\begin{array}{l}\text { Dorset } \\
\text { x Tas- } \\
\text { manian } \\
\text { Merino }\end{array}$ & $\begin{array}{l}\text { South- } \\
\text { down x } \\
\text { Dorset }\end{array}$ & $\left|\begin{array}{l}\text { South- } \\
\text { down } x \\
\text { Corrie- } \\
\text { dale }\end{array}\right|$ & $\begin{array}{l}\text { Suoth- } \\
\text { down x } \\
\text { (Dorset } \\
\text { x Tas- } \\
\text { manian } \\
\text { Merino) }\end{array}$ & $\left|\begin{array}{c}\text { South- } \\
\text { down } x \\
\text { (Dorset } \\
\text { x De- } \\
\text { laine } \\
\text { Merino) }\end{array}\right|$ & $\left|\begin{array}{c}\text { South- } \\
\text { dale } x \\
\text { Corrie- } \\
\text { dale }\end{array}\right|$ & \begin{tabular}{|l} 
Summary \\
of all \\
breeds \\
and \\
crosses
\end{tabular} \\
\hline Number of matings & 51 & 47 & 69 & 96 & 77 & 49 & 4 & 393 \\
\hline $\begin{array}{l}\text { Number of lambs raised } \\
\text { Number of lambs raised }\end{array}$ & 33 & 33 & 52 & 47 & 63 & 27 & 4 & 259 \\
\hline $\begin{array}{l}\text { per } 100 \text { matings } \\
\text { Average slaughter age }\end{array}$ & 65 & 70 & 75 & 49 & 82 & 55 & 100 & 66 \\
\hline of lambs (days) & 96 & 95 & 98 & 111 & 110 & 97 & 107 & 103 \\
\hline $\begin{array}{l}\text { Average slaughter grade } \\
\text { of lambs }\end{array}$ & $\left|\begin{array}{c}2 \\
(\text { good })\end{array}\right|$ & $\begin{array}{c}3+ \\
(\text { top } \\
\text { Mediun })\end{array}$ & $\mid \begin{array}{c}1+ \\
(\text { top } \\
\text { Choice) }\end{array}$ & $\left|\begin{array}{c}1- \\
(10 w \\
\text { Choice) }\end{array}\right|$ & $\left|\begin{array}{c}1 \\
\text { (Choice) }\end{array}\right|$ & $\begin{array}{c}2+ \\
\text { (top } \\
\text { Good) }\end{array}$ & $\begin{array}{l}2- \\
(10 w \\
\text { Good) }\end{array}$ & $\begin{array}{c}1- \\
(10 w \\
\text { Choj.ce })\end{array}$ \\
\hline $\begin{array}{l}\text { Average slaughter weight } \\
\text { of lambs (pounds) }\end{array}$ & 62 & 59 & 56 & 59 & 59 & 55 & 62 & 58 \\
\hline Average value of fleeces & & & & & & & & \\
\hline $\begin{array}{l}\text { per mating (dollars) } \\
\text { Average annual income }\end{array}$ & 1.47 & 2.00 & 1.54 & 2.40 & 2.32 & 1.59 & 4.05 & 2.00 \\
\hline $\begin{array}{l}\text { per mating (dollars) } \\
\text { Average annual cost }\end{array}$ & 7.02 & 7.90 & 10.46 & 7.37 & 12.40 & 6.17 & 15.05 & 8.85 \\
\hline per mating (dollars) & 6.16 & 6.07 & 6.52 & 5.82 & 7.46 & 5.46 & 10.88 & 6.34 \\
\hline $\begin{array}{c}\text { Average annual net return } \\
\text { per maiting (dollars) }\end{array}$ & 0.87 & 1.83 & 3.94 & 1.55 & 4.94 & 0.72 & 4.17 & 2.50 \\
\hline
\end{tabular}


The number of lambs raised per 100 matings was 100 , or the largest, for the Coiriedale ewes bred to a Southdale ram, but as this involved only 4 matings it can not be considered decisive. The Dorset x Tasmanian Merino ewes bred to Southdown rams raised 82 lambs per 100 matings, which was the leading significant figure on this item. These Dorset $x$ Tasmanian Merino ewes in the same matings to Southdown rams produced lambs averaging choice in market grade and selling so well in the hothouse lamb market that these crossbred ewes averaged the highest annual net return of $\$ 4.94$ per mating.

The results of this series of experiments show that either Dorset or Dorset $x$ Merino ewes mated with Southdown rams are able to produce hothouse lambs with the greatest net profit of any breed combinations tested in this project.

The average annual net return of $\$ 4.17$ for the 4 Corriedale ewes bred to a, Southdale ram is not a decisive result because of the small mumer of matings. Those 4 ewes yielded heavy, valuable fleeces of wool, and since they also raised a lamb apiece, their returns were relatively high.

The Dorset ewes were very good mothers and when they were mated with Southdown rams their lambs averaged top Cloice in slaughter grade, the highest average grade for any group.

The Corriedale ewes bred to southdown rams produced lambs averaging low Choice in slaughter grade, but these Corriedale ewes were not so inclined to conceive in the summertime and they averaged only 49 lambs raised per 100 matings.

The Dorset x Delaine Merino ewes were purchased as yearlings for this experiment. While they were the best that could be obtained at the time, they had a slow start in their develcpment which apparently retarded their conception in the warm summertine of their iirst year so that they raised an average of only 55 lambs per 100 matings. Although their lambs graded an average of top Good their net returns permating were only $\$ 0.72$. If it rad been possible tuproduce the Dorset x Delaine rerino ewes right on the Morgan Horse Farm under the same good conditions and from good parent. stock similar to those that produced the other crossbred ewes of this project, it is believed the Dorset $x$ Delaine Mierinos would have given a better account of them selves as producers of hothouse lambs.

Farmers who specialize in hothouse-lamb producticn need breeding ewes that will conceive during the sumer months. These experiments suggest that well-grown Dorsets or Dorset Merinos may approach this characteristic as well as or better than any breed or breed combination yet tested. The results also point to the aclvantage of Southdown rams as sires of hothouse lambs.

\section{Extra-seasonal breeding in sheep}

In the production of hothouse lambs it is important that ewes breed outside the usual fall breeding season for sheep. A study of the records obtained in the hothouse lamb work at Middlebury revealed that ewes of the Corriedale, Dorset, Tasmanian Merino, Dorset x Tasmanian Merino, and Dorset x Delaine Merino types at Middlebury tend to pass through an anestrous period during the summer months. The 
proportions of such ewes that settled during June, July, and August were small. In the Corriedale, Dorset, and Dorset $x$ Tasmanian Merino types the proportions that settled during May were higher than in the three succeeding months. In Tasmanian Merino ewes none settled during July, and in Dorset $x$ Tasmanian Merino and Dorset $x$ Delaine Merino ewes none settled during June. These data, along with results of studies at Beltsville, Md., and elsewhere, indicate that some breeds do not have two breeding seasons (as is sometimes stated) but that the series of estrous cycles which begins in the fall may extend over into the following summer and in some cases may continue throughout the year. If the series of cycles is interrupted by pregnancy they do not start again in some breeds which have a limited breeding season, while in others an additional series of estrous periods may occur during the spring and early summer months.

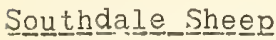

Southdale sheep have resulted from cross-breeding Southdowns and Corriedales Most of the original crosses were from Southdown rams and Corriedale ewes, but some very good original crosses were the offspring of Corriedale rams and Southdown ewes. The crossbred ewes and rams and their decendants have been interbred without backcrossing to either parent stock.

In the fall of 1929 the Bureau of Animal Industry began the mating of Corriedale ewes with Southdown rams in oross-breeding experiments for the study of the producof market lambs. This work was initiated at the United States Sheep Experiment Station, Dubois, Idaho. The resulting Southdown x Corriedale lambs grew and fattened so well on the high lush range forage west of Yellowstone Park and were so much in demand by packers on the Chicago market that the Bureau sheep specialists thought such. sheep should be useful for lamb and wool production in New England.

In the fall of 1930 work began on the effort to determine the practicability of Southdown x Corriedale sheep under conditions that exist at the Morgan Horse Farm. A choice selection of Southdown rams and Corriedale ewes were mated and in 1931 their offspring showed so much promise for the producticn of high-quality lamb meat and wool that these matings were repeated in the fall of 1931 . By the fall of 1932 some choice Corriedale rams and Southdown ewes were mated and their offspring were found very satisfactory. As the Corriedale ewes and Southdown rams were thereafter most available they were mated in the years 1936 and 1939. The offspring from these matings were the foundation parents for the strain of sheep that has been named the "Southdale." The crossbred rams and ewes and their descendants have been interbred without backcrossing to either the Southdown or the Corriedale.

The excellent mutton characteristics of the Southdown and the good wool characteristics of the Corriedale are the important factors which it is hoped may be combined in this strain of sheep. They are producing both wool and lamb meat of high quality. Southdales are small to medium in size and the lambs finish at the handy weights of 70 to 80 pounds, producing cuts of the size so much desired by many city consumers of lamb meat. Mature rams in good breeding condition weigh 140 to 175 pounds, the ewes in the fall, just after weaning their lambs, average about 115 pounds, and weaned lambs in good feeder condition abcut 50 to 60 pounds. The annual fleece weights of mature ewes average about 7 pounds of relatively clean wool, grading chiefIy $3 / 8$ blood and $\frac{1}{2}$ blood. These fleeces yield about 50 to 55 percent clean scoured woOl. 
The Southdales are hornless and average very light brown or mouse color on face and legs, but they vary from the white of the Corriedale to the light brown or mouse color of the Southdown. Selections are tending toward the blend of these colors, or very light brown or mouse color.

\section{Multi=nippled_ sheep}

A flock of 65 multi-nippled sheep was obtained late in 1941 from the New Hampshire Experiment station. These animals are descendants from an original flock developed by Alexander Grahan Bell who undertook to fix in these sheep the characteristics of four or more nipples per ewe together with multiple births of two or more lambs from a ewe at one time and the required capacity of the ewes to produce sufficient milk to raise the extra lambs successfulJy. Bell spent 30 years developing his flock from sheep of miscellaneous breeding that were obtained from farmers in Nova Scotia. After his death a portion of it was turned over to the New Hampshire Experiment station. There the multi-nippled sheep were crossed with a group of Southdown x Rambouiliet sheep developed by Prof. E. G. Ritzman. A nipple character was well fixed in this flock, an additional cross was made which gave the major portion of the flock the appearance of a standard breed. This was done through the use of Suffolk rams which possessed the multi-nippled character. and which were from multi-nippled Suffolk ewes. In the hands of the New Hampshire Station these animals proved to be good milk producers and produced a large number of multiple births. The work will be continued, selecting for the multi-nippled and mutiple birth characteristics and insofar as possible these characteristics will be îxed genetically. Additional. studies are also planned on the milk-producing capacity of these sheep.

\section{Experimental Work_with Dua l-Purpose_Cattle}

A small herd of Milking Shorthorn cattle was established in 1925 and maintained until the fall of 1941. Foundation animals came from a number of Milking Shorthorn herds in the Northeastern States. The most important work with these animals was obtaining data on milk and fat production in Milking Shorthorns and the proving of bulls. Record-of-merit testing was started in 1935 and 28 records were completed. All but two of them were based on two milkings a day. One cow made three records averaging 10,312 pounds of milk and 412 pounds of butterfat for the lactation. The production records for the various age groups are summarized below:

\section{$\underline{\text { Age }}$ 으드으}

Junior 2-year-old

Senior 2-year-old

Junior 3-year-old

Senior 3-year-old

Junior 4-year-old

Senior 4-year-old

Five-year-old or over
Ave. of all records

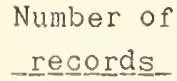 \\ Number of}

9

5

2

1

1

4

6

Average milk
_production
Pounds
$6,359.6$
$7,157.7$
$6,908.8$
$11,186.1$
$9,043.7$
$8,699.8$
$8,631.9$

Average

fat_test Per $\underline{\text { cent }}$

4.03

3.84

4. 10

3.91

3.84

4. 21

3.88

Average butterfat production. Pounds 256.8 274.9 282.4 437.8 347.2 366. 2 335.2 
Although the numbers are not large they give some indication of the producing capacity of Milking Shorthorns under conditions such as those at Middlebury. In this work the herd has been managed in a manner consistent with good farm practice, particular attention being paid to good pastures and the utilization of these pastures in milk production.

The lines of breeding in this herd were similar to those in the herd maintained at the Beltsville Research Center, Beltsville, Md, and at frequent intervals there was a transfer of animals from one herd to the other.

In the fall of 1941 it became necessary to curtail some of the activities at Middlebury and since a considerable amount of work with dual-purpose cattle was being done at Beltsville, Md., it was decided, in the interest of economy and efficiency, to discontinue the dual-purpose cattle work at Middlebury. Most of the females that were in the herd are now in the hands of the New Hampshire Agricultural Experiment Station at Durharn where they are being used along with Milking Shorthorns that were already being maintained by the New Hampshire station.

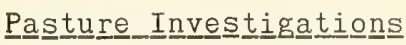

The northeastern region of the United States is one of the most important natural grass areas of the entire Nation. Since approximately one-fourth of the population of our country is at the very door of this region there is a large nearby market for livestock and livestock products. It is a region particularly favorable to increased pasture development and increased economy of production which comes from the proper utilization of pasture and forage in the production of livestock and livestock products demanded by this large consuming public.

In the spring of 1931 pasture investigations were formally initiated at the U. S. Morgan Horse Farm through the cooperation of the Vermont Agricultural Experiment Station with the Bureaus of Plant Industry and Animal Industry of the U. S. Department of Agriculture. The object of this pasture study was to survey pasture conditions and practices, to search for the most desirable grasses and other forage crops for use in the pastures, and to study the problems of maintaining and utilizing pastures in Vermont and in other northeastern States.

The survey of the pastures at the Morgan Horse Farm revealed the need for improving the quality of the forage, especially in the pastures that had for several years been pastured exclusively by horses. Those pastures were declining in palatable forage plants, and harmful weeds were seriously increasing. Correction of this situation was undertaken by grazing sheep on these horse pastures, by seeding them with such palatable forages as Kentucky bluegrass, timothy, orchard grass, meadow fescue, alsike clover, red clover, and white Dutch clover, and by fertilizing with manure, lime, superphosphate, muriate of potash, and ammonium sulphate. Seeding without soil preparation was compared with seeding after plowing and after disking. The project continued until 1939 with many tests and comparisons of forage varieties, fertilizers, and soil treatments. The experimental pastures were grazed rather extensively with sheep, but also with cattle and horses to observe the palatability of the various forages and their relative carrying capacity. Over 1,000 pasture and forage plant selections were observed in the search for the best varieties. 
Briefly the outcome of these pasture investigations was a great improvement of pastures on the Morgan Horse Farm and a demonstration of the advantages to be gained by proper soil treatment, seeding, and grazing management. The grazing of the horse pastures with sheep part of the time helped to reduce the growth of harmful weeds, and to make way for the growth of the palatable forage. Although intensive pasture research was desired by all specialists and agencies concerned, opportunity was limited for including specialized agronomic work along with the specialized livestock breeding investigations that constitute the major objective of the Morgan Horse Farm. So when the regional laboratory for pasture research was established with headquarters at Pennsylvania State College these cooperative pasture studies at the Morgan Horse Farm were concluded, but the findings are still being applied.

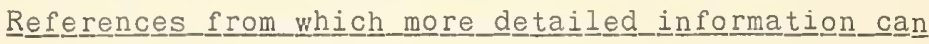

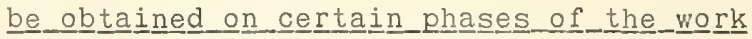

Bell, Alexander Graham.

1923. Saving the Six-Nippled Breed. Jour. Hered. 14: 98-111.

Lambert, W. V., Speelman, S. R, and Phillips, R. W.

1939. The Reproductive History of the Stud at the United States Morgan Horse Farm from 1928 to 1938. Am. Soc. An. Prod, Proc., pp. 358-365.

Phillips. Ralph W., Brier, G. W., and Lambert, W. V.

1940. A Study of Some Problems Involved in Measuring Performance in the Horse. Rotoprinted publication of the Animal Husbandry Division, Bureau of Animal Industry, U. S. Dept. of Agriculture.

Phillips, Ralph W., Speelman, S. R., and Williams, J. 0.

1942. Horse Breeding Research at the U. S. Morgan Horse Farm. Vt. Horse and Bridle Trail Bulletin, January issue.

Reese, H. H.

1923. Breeding Morgan Horses at the U. S. Morgan Horse Farm, U. S. Dept. of Agriculture, Dept. Circ. 199.

Ritzman, E. G.

1933. The Multinipple Trait in Sheep and its Inheritance. Univ. of New Hampshire Expt. Sta., Tech, Bull, 53.

Ritzman, E. G.

1941. Research of the New Hampshire Experiment Station in Animal Breeding and Nutrition. Agric. Expt. Sta., Univ, of New Hampshire, Bull. 331.

Schott, R. G., Phillips, R. W., and Spencer, D. A.

1939. The Occurrence of Estrus in Sheep and its Relation to Extra-Seasonal Production of Lambs. Am. Soc. An. Prod., Proc., pp. 347-353. 